\title{
Stock Market Development and Economic Growth: Empirical Evidence from Some Arab Countries *
}

\author{
Dr. Mahmoud Abdel-Aziz Touny \\ Assistant Professor in Economics \\ Administrative Sciences Department \\ Riyadh Community College \\ King Saud University \\ Kingdom of Saudi Arabia
}

\begin{abstract}
:
This study aims to provide further empirical evidence about the relationship between stock market development and economic growth by utilizing unbalanced panel data from some Arab countries (Bahrain, Egypt, Jordan, Oman, Qatar, Saudi Arabia, Tunis, and United Arab Emirates) over the period (1980 - 2008). The results of both fixed and random effects models indicate that there is a positive effect of stock market development (as measured by Market Capitalization Ratio and Turnover Ratio) on economic growth. This result supports the viewpoints that stock market development can enhance economic growth, and counters the skeptic's point of view that the volatile nature of stock markets and speculation in developing countries may retard economic growth. On the other hand, the results support that economic growth has positive and statistically significant influence on stock market development indicators. This conclusion points out that there is a reciprocal relationship between stock market development and economic growth. The results of this study provide some policy issues in which policy makers in Arab countries should play an active role to foster the stock markets of these countries through removing the legal and regulatory impediments to Arab stock markets and realizing the international integration of these markets.
\end{abstract}

\section{Introduction:}

Over the last two decades, a large number of developing countries have witnessed a growing importance of the financial sector in the economic life accompanied by a rapid expansion in international capital flows, especially to those countries. More specifically, stock markets in emerging markets have seen considerable development since the early 1990s. For instance, market capitalization of emerging markets has more than doubled over the past decade, growing from less than $\$ 2$ trillion in 1995 to about $\$ 5$ trillion in 2005. Emerging markets have participated by more than 12 percent of the world market capitalization and they are steadily growing (Standard and Poor, 2005). This surge in the market capitalization of emerging countries' stock markets also

* The Author Extend His Appreciation to the Deanship of Scientific Research at King Saud University for Funding the Work Through the Research Group Project No. RGP-VPP-076.

* This Research was Submitted in October 2010, and Accepted for Publishing in June 2011. 
reflects a sense by investors that those areas represent better investment opportunities compared to Western or industrialized nations. Add to that, recent years have witnessed a wave of liberalization of the financial sector in general and the stock market in particular. These trends raise two important questions for researchers and policymakers in developing countries. First, does the rapid development of stock markets in developing countries enhance their economic growth levels? Second, does liberalizing international portfolio flows enhance stock market development and promote long-run economic growth? The growing importance of stock markets in developing countries around the world over the last few decades has shifted the focus of researchers to explore the relationship between stock market development and economic growth (Deb and Mukherjee, 2008).

There is a great debate among economists regarding the connection between financial development and economic growth. The idea that financial markets may be related with economic growth is not new. Gurley and Shaw (1955) concluded that financial markets affect economic development through enhancing physical capital accumulation. However, the relationship between financial markets and real output suffered from a lack of evidence until the 1970s when studies by Goldsmith (1969), Shaw (1973) and McKinnon (1973) found that development of financial markets was significantly correlated with the level of per capita income (Caporale et. al, 2004).

Although the debate about the linkage between financial markets and economic growth is not new, the evolution of stock markets especially in emerging economies and its potential impact on economic development represents a new scope of interest among researchers in recent years, and is yet relatively unexplored. Rousseau and Sylla (2003) suggested that a well functioning securities market is one of the five important components of a good financial system that supports economic growth.

In fact, it is unclear whether emerging stock markets in Arab countries have the same positive impact on economic growth as some other emerging and developed markets have, or the volatile nature of these markets and speculation are unfavorable to economic growth. Thus, the purpose of this paper is to fill this gap in the literature and examines the potential effects of stock market development of some Arab countries on their economic growth levels, in order to give some conclusions for policymakers about how they can improve their capital markets, and hence, benefit the global economic growth. The main hypothesis of this study is to investigate whether stock market development indicators (Market Capitalization Ratio, Turnover Ratio, and Total Value Traded Ratio) have a significant effect on economic growth or not. In order to examine this relationship, we depend on a panel data set of eight Arab countries for varying time periods that cover the period 1980-2008, and apply common methods that deal with panel data which are Fixed Effects (FE) and Random Effects (RE) models.

The remainder of this study is organized as follows: Section II briefly explains the theoretical review about the relationship between stock market development and economic growth, while evidence from recent empirical studies about this relationship is discussed in section III. In section IV, we introduce data description and 
methodology used in this study. The analysis of the results of the estimated econometric models is reported in section IIV, whereas section IIIV presents conclusion and policy implications.

\section{The Theoretical Review about the Relationship between Stock Market Development and Economic Growth:}

The issue of the relationship between financial development and economic growth has been of great interest and generated considerable amount of debate among economists for many years. The debate primarily focused around two major questions: first, is there at all a relationship between financial development on economic growth?, and second, what could be the nature and direction of the causal relationship, if any?

Traditional growth theories point out that there is no correlation between stock market development and economic growth because they focus on steady-state level of capital stock per worker or productivity, but not on the rate of growth ${ }^{(1)}$. Moreover, Singh (1997) argued that stock markets are not necessary institutions for achieving high levels of economic development, but rather represent an agent that hinders economic growth. He viewed that the volatile nature of stock markets in many developing countries leads to market failure. Furthermore, Bhide (1993) indicated that individuals especially in developing countries may increase investment returns by speculating in the stock market, which in turn may be unfavorable to economic growth. Add to that, official interference in financial activities may represent an instrument that retards economic growth (Roubini \& Sala-I-Martin, 1991; Levine, 1991).

Lucas (1988) stated that economists badly overemphasize the role of finance in economic growth. Other development-economists have expressed their skepticism about the significance of the role of finance by ignoring it all together. Keynes' philosophy in which he pictured the stock market as a casino may be viewed as a consequence of the viewpoint that the financial system does not matter to a country's growth. He argued that investors are guided by short-run speculative motives, and thus they are not interested in assessing the present value of future dividends and holding an investment for a significant period, but rather in estimating the short-run price movements (Azarmi et. al, 2005). Other economists argue that economic growth is a complex process that is influenced by more factors, other than the capital market development. Add to that, capital market development is the results of many influence factors. As there are several interdependencies between these factors, so it is difficult

(1) Harrod-Domar growth theory and neoclassical growth theory argued that technical progress is exogenously determined. Solow (1956) illustrated that sustained economic growth occurs through factors of production. The neoclassical production function relates output to factor inputs, which consist of the stock of the accumulated physical capital goods and labor that is regarded as one type. The part of output growth that cannot be explained by the growth in production factors is often called the Solow residual. Thus, the neoclassical theory gives no economic explanation for technical development as a source of economic growth, but instead it includes time trend in the model for the long-run economic growth. 
to establish and isolate the causal relation between the economic growth and the capital market development (Brasoveanu et. al, 2008).

On the other hand, the possible directions of causality between financial sector development and economic growth were explained by Patrick (1966) in his 'supply leading' and 'demand following' hypotheses. The 'supply leading' hypothesis indicates that a causal relationship from financial development to economic growth as intentional creation and development of financial institutions and markets would increase the supply of financial services and thus lead to economic growth. Demand following hypothesis, however, claims that economic growth causes increased demand for financial services which in turn leads to development of financial markets (Deb and Mukherjee, 2008).

Stiglitz (1989) illustrated that under certain conditions, the existence of market imperfections implies that certain forms of official intervention improve resource allocation and corporate control. The recent interest in the link between financial development and growth depends mainly on the techniques of endogenous growth models, which have shown that there can be self-sustaining growth without exogenous technical progress and that the growth rate can be related to preferences, technology, income distribution and institutional arrangements. This supports recent theoretical literature that early contributions did not consider that financial intermediation can be shown to have not only level effects but also growth effects (Vazakidis and Adamopoulos, 2010). Theoretical literature of the endogenous growth theory suggests that a well-developed stock market may promote risk diversification, liquidity, information processing, and capital mobilization that in turn may enhance long-run economic growth. Proponents of this theory argue that the stock market is an economic institution, which promotes efficient allocation of capital. It gives lenders the opportunity to diversify their investments and enables governments and industry to raise long-term capital for financing new projects, expanding and modernizing current investments. In the absence of stock markets, industries with growing demand that are capable to expand their production and increase their productivity may suffer from limited financing resources, which in turn may inhibit the growth rate of the economy. In this behalf, the stock market provides a long-term, non-debt financial capital, through the issuance of companies' equity securities, and thus protects companies from over dependence on debt financing. The allocation of these resources is managed by forces of demand and supply that direct resources toward firms with relatively high productivity and expected return. In that case, the stock markets represent significant economic functions even in those economies in which there already exists a welldeveloped banking sector. It is argued that equity and debt financing are not perfect substitutes in imperfect markets. Therefore, a well-developed stock market leads to an increase of savings and an efficient allocation of capital to more productive investments (Levine, 1991, 1993, 1997a, 1997b; Baier et. al, 2004; Capasso, 2003).

Liquidity of investments in stock markets represents one channel that can promote economic growth. As economies develop, more funds are needed to meet rapid expansion of these economies. The stock market improves the mobilization of savings 
and the allocation of resources among competing uses. It is supposed that the stock market promotes savings by providing individuals with an additional instrument that may be better to meet their risk preferences and liquidity needs (Caporale et. al, 2005). Levine (1991) and Bencivenga and Smith (1991) argued that more liquid stock markets stimulate long-run investment as investors have immediate access to their funds if they need liquidity before the project matures, while simultaneously offer borrowers longterm supply of capital. As a result, high liquid stock markets stimulate investment toward long-run projects with high expected returns and thus boost productivity growth.

However, the effect of greater liquidity on saving rates and thereby economic growth is ambiguous. Greater liquidity leads to an increase in investment returns and lowers uncertainty. First, higher returns ambiguously affect saving rates due to income and substitution effects ${ }^{(2)}$. Further, lower uncertainty ambiguously affects the savings rate because it is a function of the degree of risk-averseness of economic agents ${ }^{(3)}$. Therefore, saving rates may rise or fall as liquidity rises (Levine, 1997a). Add to that, some economists argue that very liquid markets may hurt economic growth by allowing investors to sell their shares quickly, and thus reduce stock owners' commitment to make corporate control by monitoring the performance of managers and firms. According to this view, greater stock market liquidity may impede economic growth by hindering corporate control which might improve the performance of firms (Levine, 1997b).

Another channel through which stock market can affect economic growth is through risk diversification. Obstfeld (1994) illustrated that internationally integrated stock markets provide opportunities for risk diversification and thus can foster more efficient allocation of resources which in turn can accelerate economic growth. As high return investments tend to be comparatively risky, stock markets that facilitate risk diversification encourage a shift to higher-return investments, and consequently can affect long-run economic growth by orienting society's savings toward projects with high expected-returns.

Moreover, improved information can improve the allocation of resources and promotes economic growth. Holmstrom and Tirole (1993) showed that information that is reflected in a firm's share price represents an important instrument for guiding firms' management to boost their productivity levels, and hence economic growth in aggregate. Furthermore, providing investors with better information about firms

(2) The net effect of higher investment returns on saving rates depends on the relative strength of the income and substitution effects between consumption today and consumption tomorrow. The substitution effect of higher investment returns is to encourage agents to sacrifice current consumption for future consumption, but the income effect is to discourage current saving by giving agents more income in the present, and the two effects may cancel each other out (Oshikoya and Ogbu, 2002).

(3) Increased uncertainty has two divergent forces on consumption and consequently on savings. The first force is the desire to consume more initially as a hedge against the uncertain future. The second force is the desire to consume less initially so as to increase the future consumption. (For more details, see: Levhari and Srinivasan (1969) \& Mirman (1971)). 
reduces information and transactions costs, which in turn minimizes liquidity risk and optimally allocates investments. Therefore, stock exchange can enhance economic growth through aggregating information about firms' opportunities that helps investors make better investment decisions, thereby directing capital to investments with high returns. By lowering information costs, financial intermediaries foster more efficient resource allocation and thereby accelerate technological innovation and long-run growth (King and Levine, 1993).

\section{The Previous Empirical Studies}

Although there are considerable theoretical studies that handle the potential linkages between stock market development and economic growth, empirical studies testing this hypothesis are relatively limited especially for developing countries. Most empirical studies done on developing countries concentrate mainly in recent years (2000s), and findings and views expressed in these works have been generally conflicting in nature. In this context, we try to explore some important recent studies that try to extract the true interactions between stock market development and economic growth.

Harris (1997) examined the empirical relationship between stock markets and economic growth using data from 49 countries over the period 1980-1991. He found no hard evidence that the level of stock market activity helps to explain growth in per capita output. After splitting the sample, however, it is found that the stock market activity only has a weak positive impact on per capita growth in developed countries, but does not offer any evidence to support this hypothesis for less developed countries.

Using data of 47 countries from 1976 to 1993, Levine and Zervos (1998) demonstrated that there is a strong relationship between measures of stock market liquidity and the three growth indicators: economic growth, capital accumulation, and productivity growth. However, the stock market size does not seem to be robustly correlated to economic growth. One disadvantage of this study is related to the estimated coefficients of the OLS regressions, which are potentially affected by simultaneity bias, and do not control for country fixed effects.

To examine the casual relationship between economic growth and stock market performance, Filer et al (1999) used Granger-causality tests and data covering the period (1985-1997) over a large number of countries with varying economic conditions and levels of stock market activity. Their results indicated that there is a strong relationship between stock market performance and future economic growth for low and lower middle income countries, but not in higher income countries or developing economies.

Gürsoy and Müslümov (2000) investigated the causal relationships between stock markets and economic growth based on Sims' causality test and time series data collected from 20 countries over the period 1981-1994. To reveal this casual relationship, they used at first panel data covering all countries over the entire analysis period, and after that causal relations for each country were examined separately using the respective time series data. Findings of panel data models revealed a two-way causation between stock market development and economic growth. With regard to 
individual countries, however, the analysis did not reach to conclusive results, but suggested somewhat a stronger link between stock market development and economic growth in developing countries.

Agarwal (2001) explored the relationship between stock market development and economic growth for nine African countries through the period (1992-1997) based on analyzing simple correlations between several indicators of stock market performance and economic growth. The study provided some evidence that stock market development is correlated with investment and in turn with economic growth. However, the results suggested that the turnover ratio (TR) is not an effective measure of stock market liquidity, which may be a special case for African countries where stock markets are highly volatile, causing the turnover ratio to be a misleading indicator of liquidity. One shortcoming of this study is that it does not conduct any regression analysis to reveal the true effect of stock market development on economic growth, which is due to the lack of data as there is not sufficient number of countries in Africa with a stock market.

In Nigeria, Osinubi (2004) employed ordinary least squares (OLS) regression to examine whether the stock market promotes economic growth using data from 1980 to 2000. The results supported a positive relationship between growth and all stock market development indicators used. However, this study did not check and deal with the problem of co-movement of most macroeconomic time series and thus OLS estimators may be spurious.

Baier, et. al (2004) examined whether the opening of the stock market is associated with faster economic growth by using data covered 145 countries for an average of 57 years. Their results demonstrated that economic growth increases relative to the rest of the world after a stock exchange opens. Furthermore, the findings pointed out that more efficient allocation of resources rather than more capital accumulation is the primary channel through which the stock market affects economic growth.

By using VAR procedures developed by Toda and Yamamoto (1995), Caporale et al (2004) tested the linkage between stock market development, bank development and economic growth using data of a sample of seven countries. The outcomes suggested that a well- functioning stock market promotes economic growth in the long-run.

In another study, Caporale et. al. (2005) provided a theoretical framework and an empirical investigation to reveal the channel through which stock markets affect economic growth in the long run. The study tried to examine the hypothesis of endogenous growth models that financial development promotes economic growth through its effect on the level of investment and productivity. The empirical part of this study used the VARs model to test this causality relationship depending on data of four countries (Chile, Korea, Malaysia and Philippines) using quarterly data over the period 1979-1998. The results suggested that investment productivity is the channel through which stock market development boosts the growth rate in the long run.

Using the autoregressive distributed lag (ARDL) bounds test, Choong et. al. (2005) provided another support for the co-integration between stock market development and 
economic growth in Malaysia through the period (1978-2000). Add to that, results of Granger-causality test based on the vector error correction model (VECM) indicated that stock market development Granger-causes economic growth. Consequently, they argued that the stock market represents a leading sector in stimulating domestic growth.

In Greece, Dritsaki and Dritsaki-Bargiota (2005) examined the causal relationship among financial development, credit market and economic growth through the period (1988:1-2002:12) by using a trivariate autoregressive vector model (VAR). Results of Granger causality tests confirmed that there is a bilateral causal relationship between banking sector development and economic growth and unidirectional causality between economic growth and stock market development.

Azarmi, et. al (2005) examined the empirical association between stock market development and economic growth for a period of 1981 to 2001 in the Indian economy, and found no support for the hypothesis that the Indian stock market development is associated with the economic growth in that country during the entire study period. However, their results supported for relevance of stock market to economic development during the pre-liberalization sub-period, and a negative correlation between stock market development and economic growth for the postliberalization period.

In an attempt to test the relationship between stock market development indicators and economic growth in Belgium post 1830, Nieuwerburgh et al (2006) demonstrated that there is a strong long-term relationship between stock market development and economic growth, especially through the period between 1873 and 1935. Add to that, it is found that the banking system was more important for economic growth before 1873 than after 1873, when the stock market took over this role.

Shahbaz et. al (2008) investigated whether there is a relationship between stock market development and economic growth in Pakistan using annual time series from 1971 to 2006. They applied Engle-Granger causality and ARDL tests to reveal the long-run causal linkages and the short-run dynamics of this relationship. The outcomes of this study provided another support that there is a very strong relationship between stock market development and economic growth. Engle- Granger Causality estimation confirmed that there is bi-directional causality between stock market development and economic growth in the long run, whereas there is only one-way causality from stock market development to economic growth in the short-run.

In India, Chakraborty (2008) tried to reveal the dynamic interactions between the growth of real GDP and indicators of financial development using a data set of the period (1996-2007). The empirical results obtained by the ADF test suggested the existence of a stable long-run relationship between stock market capitalization, bank credit and the growth rate of the real GDP. However, the results supported one way direction of causality that runs from economic growth to stock market capitalization.

In another study, Deb and Mukherjee (2008) re-examined the causal relationships between the real GDP growth rate and stock market development for the Indian 
economy through the same period (1996-2007) using Granger causality test proposed by Toda and Yamamoto (1995). This study concentrated mainly on stock market development and its causal linkage with economic growth, rather than interactions between the growth of the real GDP and broad indicators of overall financial development as was manipulated by Chakraborty (2008). Deb and Mukherjee showed that there is strong unidirectional causality from both stock market activity and volatility to real GDP growth. Moreover, the results supported a bi-directional causal relationship between real market capitalization ratio and economic growth.

Using Granger causality tests based on the Vector Error Correction Model (VECM), Vazakidis and Adamopoulos (2009) investigated the long-run causal relationship between financial development and economic growth in Greece over the period 1978-2007. The results indicated that economic growth has a positive effect on stock market development and credit market development through the industrial production growth in Greece. Also, Vazakidis and Adamopoulos (2010) reexamined the causal relationship between financial market development and economic growth for United Kingdom for the period 1965-2007 using a Vector Error Correction Model. The results of Granger causality tests indicated that there is a bilateral causal relationship between economic growth and financial market development.

In sum and from the previous empirical studies, we can conclude that the linkages between stock market development and economic growth have been inconclusive, even though the balance of evidence is in favor of a positive relationship between stock market development and economic growth. As we see, some studies supported a bi-directional relationship, whereas others supported one way direction that may be from economic growth to stock market development or from stock market development to economic growth. Moreover, while some studies confirmed the strong interactions between stock market development and economic growth especially in less developed countries, others demonstrated that these strong linkages exist only in developed countries but not in developing or less developed countries. According to that, and due to the limited studies applied on Arab countries, this study tries to reexamine this relationship depending on a panel data set of some Arab countries.

\section{Data Description and Methodology Used}

The first part of this section describes the various measures of stock market development and economic growth used in this paper, and presents some general trends and summary statistics of the variables under study. After that, we discuss the model used to estimate the relationship between stock market development and economic growth.

As most used in many empirical studies, economic growth is measured by the growth rate of current GDP (GGDP). With regard to the stock market development, three proxies are used in this study in an attempt to reveal the true relationship between stock market development and economic growth. These proxies are:

- MCR: Market Capitalization Ratio (size proxy) is defined as the ratio of market capitalization to current GDP. It is assumed that the overall market size is 
positively correlated with the ability to mobilize capital to investment and diversify risk to investors.

- TR: the Turnover Ratio (liquidity proxy) is defined as the value of all traded shares divided by market capitalization. High TR is often used as an indicator of low transactions costs. We should note that a large stock market is not necessarily a liquid market, as a large but inactive market will have large capitalization but small turnover.

- TVTR: the Total Value Traded Ratio (another liquidity proxy) is defined by the ratio of the total value of all traded shares to current GDP, and thus positively reflects liquidity on an economy-wide basis. However, TVTR may be different from TR as TVTR reflects trading relative to the size of the economy, whereas TR measures trading relative to the size of the stock market. Thus, a small, liquid market will have high TR but small TVTR (Levine, 1991).

One problem arising from using TVTR in the model is that the potential effect of share prices on the value traded (the price effect). If there is an anticipation of high corporate profits in future, this will lead to a current increase in stock prices, which in turn will result in an increase in the value of transitions and therefore a rise in TVTR. In this case, rising up TVTR refers to an increase in market liquidity without an increase in the number of transactions or a decrease in trading costs. One way to measure the importance of the price effect is to incorporate both TR and TVTR together in the regression model. In general, the price effect does not influence TR because stock prices enter the numerator and denominator of TR. Therefore, if TR has a positive and statistically significant effect on economic growth, this involves that the price effect is not the dominant factor on the relationship between liquidity and economic growth (Levine and Zervos, 1998).

The study covers eight Arab countries that have a stock market, and have relatively reasonable time series data about stock market indicators. These countries are: Bahrain, Egypt, Jordan, Oman, Qatar, Saudi Arabia, Tunis, and United Arab Emirates. Our original intention was to cover all Arab countries, but given that some countries have not yet established stock markets (for example, Iraq, Libya, Sudan, Syria and Yemen), and data from some other countries is not available in time series, the sample countries included only eight Arab countries. The number of time observations ranges from seven annual observations for Tunis to 29 observations for Jordan. As a result, we can't estimate a model for each country due to the short time series for some countries, and thus we pooled observations across countries to create an unbalanced panel data set.

Data of current GDP for all countries was got from International Monetary Fund, World Economic Outlook Database, October 2009. With regard to the data of the stock market indicators, we depended on the available data published from each country's stock market (see appendix (1) for more details about data sources). The panel data set used in this study covers 133 country/year observations for varying time periods that cover the period 1980-2008. 
Table (1) provides trends of the stock market development indicators during the study period. It is observed that liquidity increased significantly in most countries of the sample during 2000s comparing to the previous period except Bahrain. For instance, TR increases from about $13 \%$ (in average) during 1980s to about $42 \%$ during 2000 s in Jordan, and from less than $18 \%$ during (1985-2000) to reach about $160 \%$ during (2001-2008) in Saudi Arabia. Similarly, this increasing trend in liquidity is reinforced by using TVTR which was much higher during (2001-2008) in most countries except Oman and Bahrain, which has a relatively illiquid stock market (see also figure 2 and 3 for more details). Moreover, these two measures of liquidity in some cases are complements for each other. For instance, in Tunis the TVTR is $5.12 \%$ (in average) during (2002 - 2008), but the TR is about $42 \%$ during the same period, which means that Tunis has a small but relatively active market.

With regard to the measure of the stock market size which is represented by the market capitalization ratio (MCR), it is observed from table (1) and Figure (1) that Jordan, Bahrain, Saudi Arabia, Qatar, United Arab Emirates, and Egypt have a relatively high market size comparing to Oman and Tunis especially during 2000s. This conclusion indicates that these countries with a relatively bigger market size have a greater ability to mobilize capital and diversify risks than those countries characterized with a relatively smaller market size.

Table (1)

Trends of Stock Market Development Indicators

Of Some Arab Countries during (1980-2008)

\begin{tabular}{|c|c|c|c|c|c|}
\hline \multirow[t]{2}{*}{ Country } & \multirow[t]{2}{*}{ Period } & \multicolumn{4}{|c|}{$\begin{array}{c}\text { Variables (in average) } \\
(\%)\end{array}$} \\
\hline & & GGDP & MCR & TR & TVTR \\
\hline \multirow{3}{*}{ Jordan } & (1980-1990) & 10.07 & $\overline{49.88}$ & 12.70 & 6.46 \\
\hline & (1991-2000) & 8.19 & 71.27 & 15.74 & 11.26 \\
\hline & $(2001-2008)$ & 11.48 & 167.43 & 42.47 & 83.63 \\
\hline \multirow{3}{*}{ Saudi Arabia } & (1985-1990) & 1.27 & 23.05 & 2.47 & 0.59 \\
\hline & (1991-2000) & 5.26 & 34.32 & 17.76 & 5.96 \\
\hline & $(2001-2008)$ & 12.49 & 95.16 & 159.54 & 165.94 \\
\hline \multirow{2}{*}{ Oman } & (1989-2000) & 7.74 & 16.99 & 23.17 & 5.43 \\
\hline & $(2001-2008)$ & 15.81 & 33.92 & 27.54 & 9.44 \\
\hline \multirow{2}{*}{ Egypt } & (1990-2000) & 14.61 & 18.19 & 19.79 & 5.06 \\
\hline & $(2001-2008)$ & 13.02 & 59.97 & 42.35 & 27.17 \\
\hline \multirow{2}{*}{ Bahrain } & (1995-2000) & 6.38 & 98.16 & 5.05 & 5.25 \\
\hline & (2001-2008) & 13.21 & 111.87 & 4.65 & 5.21 \\
\hline Qatar & $(1997-2008)$ & 23.49 & 82.73 & 18.54 & 19.99 \\
\hline United Arab Emirates & $(2001-2008)$ & 18.60 & 74.79 & 48.79 & 41.60 \\
\hline Tunis & $(2002-2008)$ & 8.34 & 11.68 & 41.89 & 5.12 \\
\hline
\end{tabular}

Source: Calculated by the author depending on the available data set. 
Stock Market Development and Economic...

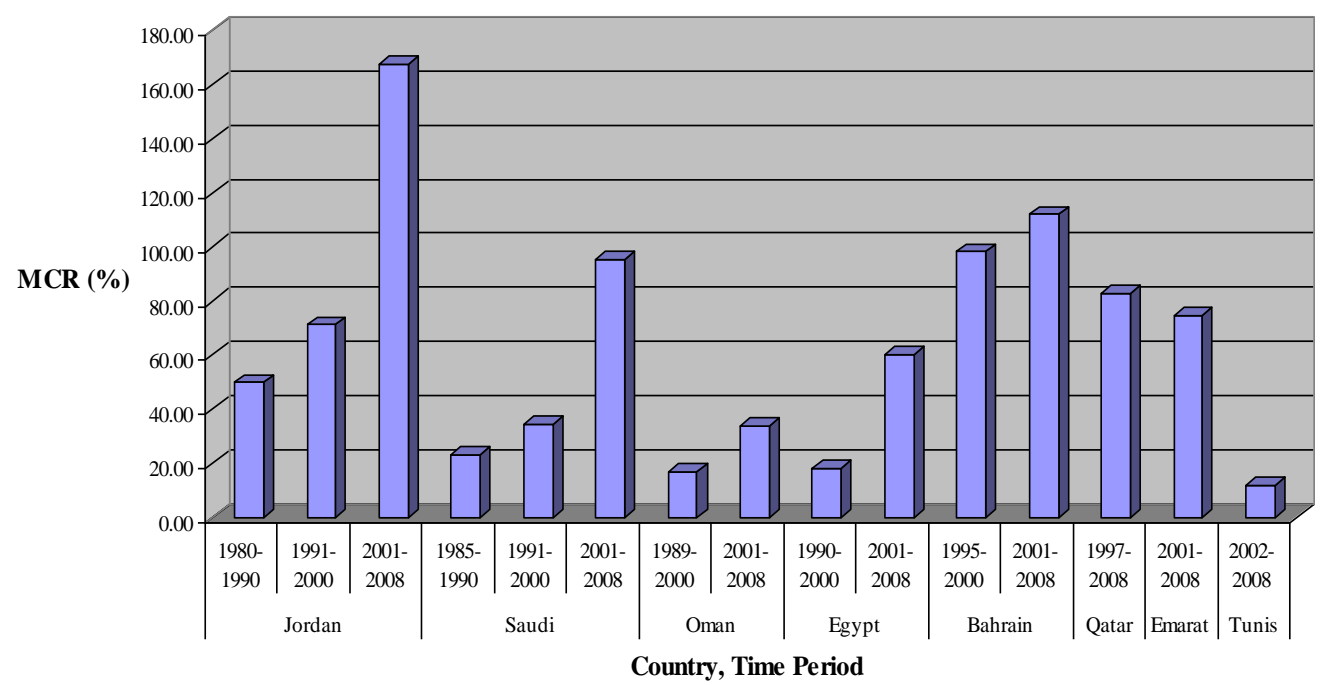

Fig. (1): The Average Size of the Stock Market

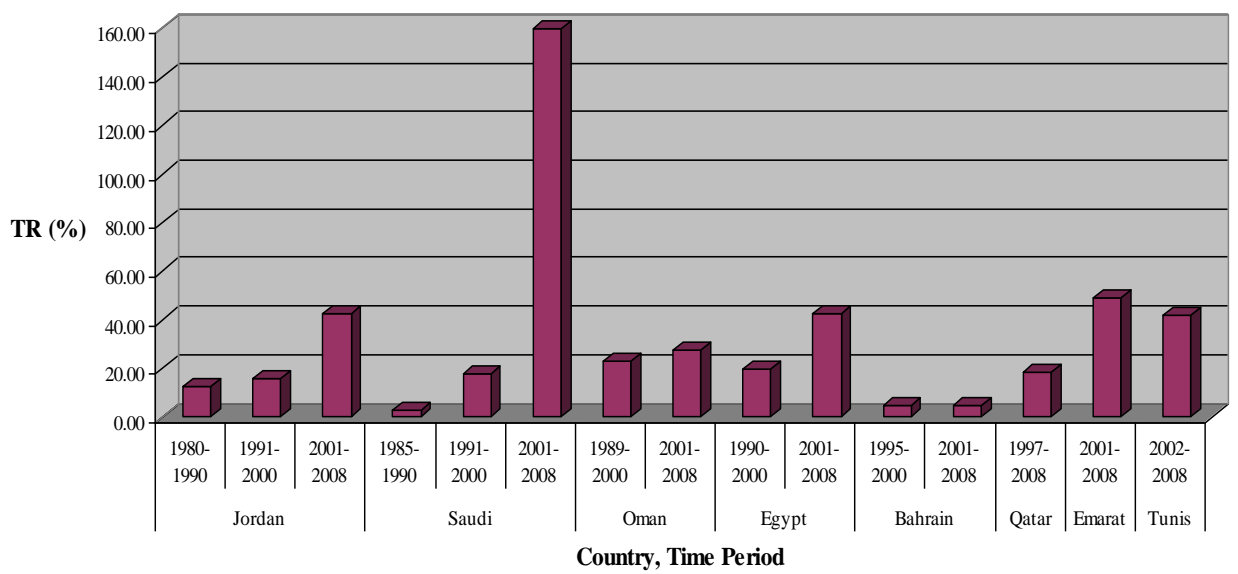

Fig. (2): The Average Market Liquidity as Measured by (TR)

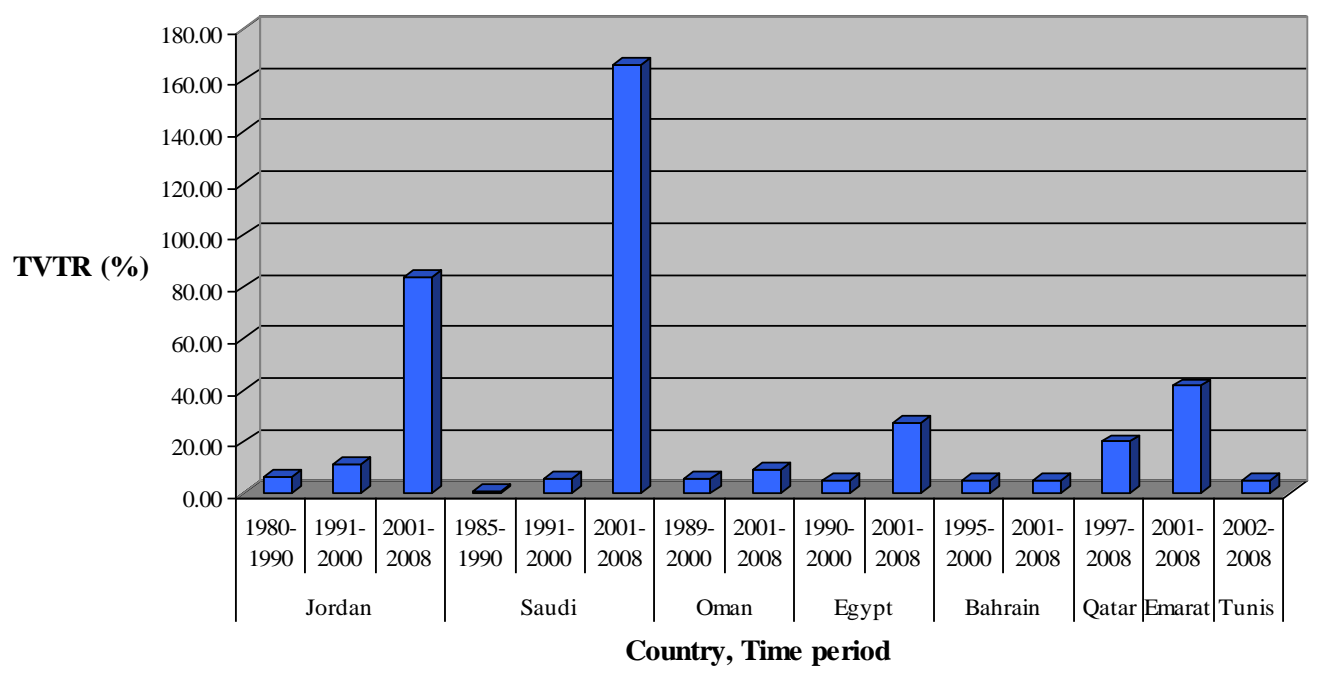

Fig. (3): The Market Average Liquidity as Measured by TVTR 
There are two common methods that deal with panel data which are Fixed Effects (FE) and Random Effects (RE) models. The fixed effects model assumes that differences between countries can be captured by differences in the intercept $\left(\alpha_{i}\right)$. It allows controlling the omitted variables that differ between cases (i.e. countries) but are constant over time. Although there are no significant temporal effects, there are significant differences among countries in this type of model. Therefore, this model allows the unobserved country effects to be correlated with the included variables. In that case, the model takes this form:

$$
Y_{i t}=\alpha_{i}+X_{i t}^{\prime} \beta+\varepsilon_{i t}
$$

Where: ${ }^{Y_{i t}}$ Is the value of the dependent variable for country $i$ in period $t$,

$X_{i t}^{\prime}$ Is $(\mathrm{Kx} 1)$ vector of independent variables of country $i$ in period $t$,

$\beta$ Is a (Kx1) vector of parameters,

$\alpha_{i}$ Is an intercept that is allowed to vary over $i$, where $\alpha_{i}=Z_{i}^{\prime} \alpha$

$Z_{i}^{\prime}$ Contains a constant term and a set of individual or group specific variables, which may be observed or unobserved. All of which are taken to be constant over time $t$.

$\varepsilon_{i t}$ Is a random error that is assumed to vary over $i$ and $t$.

This fixed effects approach takes $\alpha_{i}$ to be a group-specific constant term in the regression model to reflect the unobserved variables that do not change over time. The fixed-effects model controls for all time-invariant differences between countries, so the estimated coefficients of the fixed-effects model cannot be biased because of omitted time-invariant characteristics such as culture, religion, etc. However, if $Z_{i}^{\prime}$ is unobserved, but correlated with ${ }^{X_{i t}^{\prime}}$, then the least squares estimator of $\boldsymbol{\beta}$ is biased and inconsistent due to omitted variables. There are two common estimators for the fixed effects model which are the least squares dummy variable (LSDV) estimator and the mean transformed data approach. In LSDV, a separate dummy variable is coded for each case and entered into the model to control for ${ }^{\alpha_{i}}$.

However, if there is a reason to believe that some omitted variables may be constant over time, but vary between cases, and other variables may be fixed between cases but vary over time, the random effects model is the appropriate method. Unlike the fixed effects model, the variation across countries in the random effects model is assumed to be random and uncorrelated with the independent variables included in the model. The estimated model in that case is:

$$
Y_{i t}=\alpha+X_{i t}^{\prime} \beta+u_{i}+\varepsilon_{i t}
$$


The model therefore has two disturbance terms, $u_{i}$ which reflects the between disturbance but constant over time, and $\varepsilon_{i t}$ that represents the within disturbance. It is assumed that unmeasured time-invariant variables that might appear in $u_{i}$ to be uncorrelated with all other explanatory variables in the analysis. If this assumption were not met, the random effect estimator would be biased. The other assumption of the random effects model is that the error variance does not change over time. One common estimator of the coefficients and variances of the error and time invariant latent variable is the feasible Generalized Least Square (GLS) estimator. A maximum likelihood estimator of the random effects model also is possible under the assumption that $u_{i}$ and $\varepsilon_{i t}$ come from a normal distribution.

The crucial distinction between fixed and random effects is whether the unobserved country effect includes elements that are correlated with the regressors in the model, not whether these effects are stochastic or not. If there is a reason to believe that differences across countries have some influence on the dependent variable, then it is preferable to use random effects. An advantage of random effects is that it could include time invariant variables; however, in the fixed effects model these variables are absorbed by the intercept.

To choose which model is more appropriate to the application, the specification test devised by Hausman (1978) is used to test for the more efficient models between fixed and random effects models. The null hypothesis is that the preferred model is random effects versus the alternative is the fixed effects. The research question is whether there is a significant correlation between the unobserved random effects and the regressors. So, it basically tests whether the unique errors $\left(u_{i}\right)$ are correlated with the regressors. The null hypothesis is that they are not. The test for this correlation is a comparison of the covariance matrix of the regressors in the LSDV model with those in the random effects model. If there is no statistically significant difference between the covariance matrices of the two models, then the correlations of the random effects with the regressors are statistically insignificant. In that case, the random effects model may be more powerful. If there is such a correlation, the random effects model would be inconsistently estimated and the fixed effects model would be the model of choice. The Hausman test is a kind of Wald chi-square test with $(k-1)$ degrees of freedom (where $k=$ number of regressors) $^{(4)}$.

\section{The Empirical Results}

As stated before, we pooled observations across countries and estimated both country-fixed and random-effect models. Results of the estimated models are reported in tables (2) and (3). The least square dummy variable model (LSDV) provides a good way to understand the fixed effects. By adding a dummy variable for each country, we

(4) For more details about fixed and random effects models see: Johnston and DiNardo (1997), Chapter 10; Greene (2003), chapter 13. 
are estimating the pure effect of explanatory variables by controlling for the unobserved heterogeneity. Each dummy is absorbing the effects particular to each country. It is observed that the results of both fixed and random effects models are similar, where the signs and significance of the coefficients do not vary significantly across the estimated models, and thus in economic terms similar conclusions can be obtained from both estimators ${ }^{(5)}$.

To choose between fixed and random effects, we run a Hausman test. It basically tests whether the unique errors $\left(u_{i}\right)$ are correlated with the regressors, where the null hypothesis is they are not. Results of Hausman test are reported in Table (4). Chisquare of the Hausman test with 3 degrees of freedom is 0.13 , which is insignificant even at $10 \%$ level of significance. This indicates that the random effects model is the appropriate model.

Furthermore, Breusch-Pagan (1980) provided an alternative test (Lagrange multiplier (LM)) for homoscedasticity and can be applied to the random effects model. The null hypothesis in the LM test is that variances across countries are zero that means there is no significant difference across countries $\left(\mathrm{H}_{0}: \sigma_{u}^{2}=0 ; \mathrm{H}_{1}: \sigma_{u}^{2} \neq 0\right)$. LM is distributed as chi-squared with one degree of freedom. Results of table (5) indicate that the value of chi-square $=21.55$, which is significant at $1 \%$, and thus we reject the null hypothesis in favor of the random effects model.

The results of the random-effects in table (3) provide evidence that there is a positive link between market capitalization and economic growth. An increase of MCR by one percentage point, leads to an increase of GDP growth by 0.056 percentage point. This result is consistent with our hypothesis that the stock market size is positively correlated with the ability to mobilize capital to investment and diversify risk to investors, which in turn has a positive effect on economic growth. Add to that, the stock market liquidity as measured by turnover ratio (TR) has a statistically positive effect on economic growth. Unlike with TR, there is no evidence that a change in the TVTR is linked to differing rates of economic growth. Although this variable has a negative sign, it does not have a statistical significant effect.

In general, these results indicate that both measures of stock market development (i.e. liquidity and market size) have a positive and significant effect on economic growth. This conclusion supports the viewpoint that stock market development can enhance economic growth, and replies on a skeptic's point of view that the volatile nature of stock markets and speculation in developing countries may retard economic growth.

(5) Policy related variables such trade openness, inflation rate and the foreign direct investment were incorporated in the models in the first stage, however, the existence of interactions among variables causes some of them, especially those variables representing stock market development, to lose significance when they are included simultaneously. Therefore, we estimated the models without these policy related variables. 
Table (2)

Results of the Fixed-effects Regression

$\begin{array}{llllr}\mathrm{R}^{2}=0.29 & \mathrm{~F}(10,122) & = & 4.99 \\ \text { Adj. } \mathrm{R}^{2}=0.23 & \text { Prob. of } \mathrm{F} & = & 0.000 \\ & & \text { Corr }\left(\mathrm{u}_{\mathrm{i}}, \mathrm{X}\right) & = & -0.077\end{array}$

\begin{tabular}{l|c|c|c|c}
\hline \hline \multicolumn{1}{c|}{ Variable } & Coefficient & Std. Error & t & P value \\
\hline \hline MCR & 0.056 & 0.032 & 1.72 & 0.089 \\
TR & 0.074 & 0.042 & 1.78 & 0.077 \\
TVTR & -0.032 & 0.046 & -0.69 & 0.494 \\
ICountry_2 & -6.111 & 3.069 & -1.99 & 0.049 \\
ICountry_3 & -5.487 & 4.249 & 0.20 & 0.199 \\
ICountry_4 & -9.146 & 3.000 & -3.05 & 0.003 \\
ICountry_5 & -2.211 & 3.044 & -0.73 & 0.469 \\
ICountry_6 & 1.907 & 4.081 & 0.47 & 0.641 \\
ICountry_7 & 7.906 & 3.697 & 2.14 & 0.034 \\
ICountry_8 & -6.042 & 3.973 & -1.52 & 0.131 \\
Constant & 10.232 & 2.626 & 3.90 & 0.000 \\
\hline Sigma $u=5.511$ & \multicolumn{4}{|c}{ F test that all $u_{\mathrm{i}}=0$} \\
Sigma $\varepsilon=9.122)=4.89$ \\
$\gamma=0.253$ \\
\hline \hline
\end{tabular}

Notes:

* $\operatorname{Corr}\left(\mathrm{u}_{\mathrm{i}}, \mathrm{X}\right)$ refers to the correlation between $u_{i}$ and the regressors in the fixed effects model.

* the $\mathrm{F}$ test is to see whether all the coefficients in the model are different from zero.

* $\gamma$ refers to the variance not explained by differences across countries.

* P value: less than 0.01 means significant at $1 \%$, less than 0.05 means significant at $5 \%$, and less than 0.10 means significant at $10 \%$.

* ICountry_2, ICountry_3, ..., ICountry_8: refer to dummy variables for countries which are Jordan, Tunis, Saudi Arabia, Oman, United Arab Emirates, Qatar, and Bahrain respectively. One country dummy variable is omitted to avoid perfect multicollinearity.

* The estimated results of Random and Fixed effects models are calculated using STATA 10 software.

Table (3)

\section{Results of the Random-effects Regression}

$$
\begin{aligned}
& \mathrm{R}^{\perp} \text { within }=0.121 \quad \text { Wald chi-square (3) }=17.31 \\
& \text { between }=0.062 \quad \text { Prob. of chi-square }=0.0006 \\
& \begin{array}{lll}
\text { overall }=0.089 & \operatorname{Corr}\left(\mathrm{u}_{\mathrm{i}}, \mathrm{X}\right) & =0
\end{array}
\end{aligned}
$$

\begin{tabular}{l|c|c|c|c}
\hline \hline \multicolumn{1}{c|}{ Variable } & Coefficient & Std. Error & $\mathbf{Z}$ & P value \\
\hline \hline Constant & 7.601 & 3.088 & 2.46 & 0.014 \\
MCR & 0.059 & 0.031 & 1.92 & 0.055 \\
TR & 0.075 & 0.041 & 1.83 & 0.068 \\
TVTR & -0.035 & 0.045 & -0.77 & 0.443 \\
\hline
\end{tabular}

Sigma u $=6.589$

Sigma $\varepsilon=9.468$

$\underline{\gamma}=0.326$ 
Table (4)

Results of Hausman Test:

$H_{0}$ : difference in coefficients not systematic

chi-square (3) $=0.13$

\begin{tabular}{l|c|c|c}
\hline \hline \multirow{2}{*}{ Variables } & \multicolumn{2}{|c|}{ Coefficients } & \multirow{2}{*}{$(\mathbf{b}-\mathbf{B})$} \\
\cline { 2 - 3 } & Fix) & $\begin{array}{c}(\mathbf{B}) \\
\text { Random }\end{array}$ & Difference \\
\hline \hline MCR & 0.056 & 0.059 & -0.003 \\
TR & 0.074 & 0.075 & -0.001 \\
TVTR & -0.032 & -0.035 & 0.003 \\
\hline \hline
\end{tabular}

Table (5)

Results of Breusch-Pagan Lagrangian Multiplier (LM) test

$H_{0}: \quad \sigma_{u}^{2}=0$

Chi-square (1) $=21.55$

Prob. of Chi-square $=0.0000$

\begin{tabular}{l|c|c}
\hline \hline \multicolumn{1}{c|}{ Variable } & Variance (Var) & Standard Deviation \\
\hline \hline GGDP & 116.74 & 10.81 \\
$\varepsilon$ & 89.64 & 9.47 \\
$\mathrm{u}$ & 43.42 & 6.59 \\
\hline \hline
\end{tabular}

It is now well recognized that stock market development has a positive impact on economic growth, however, this relationship can go in the other direction. In other words, economic growth can also promote stock market development. This view refers to the reciprocal relationship between stock market development and economic growth. To investigate this reverse direction, we incorporate the variable representing economic growth on the right hand side of the model, and use the indicators of stock market development separately on the left hand side. Table (6) reports the results of these estimated models. Findings of these regressions indicate that economic growth (in both level and lag structure) has a positive and statistically significant effect on the three indicators of stock market development at least at 5\% level of significance. These results suggest that high economic growth may create demand for various financial services and consequently stock markets are effectively responding to these changes.

In sum, the previous results suggest a two-way causal relationship between stock market development and economic growth. Under this conclusion, we can say that a country with a well-developed stock market could promote high economic expansion through risk diversification and reallocation of resources towards more productive investments. In turn, higher economic performance will create high demand on the financial instruments and services and so the stock market effectively responds to these demands. Therefore, both stock market development and economic growth are positively interdependent. 
Table (6)

Results of the Random Effects of the Reverse Models

\begin{tabular}{|c|c|c|c|c|c|c|c|c|c|}
\hline \multirow{2}{*}{$\begin{array}{l}\text { Independent } \\
\text { Variables }\end{array}$} & \multicolumn{3}{|c|}{$\begin{array}{c}\text { Model (1) } \\
\text { Dependent variable: } \\
\text { MCR } \\
\end{array}$} & \multicolumn{3}{|c|}{$\begin{array}{c}\text { Model (2) } \\
\text { Dependent variable: TR }\end{array}$} & \multicolumn{3}{|c|}{$\begin{array}{c}\text { Model (3) } \\
\text { Dependent variable: } \\
\text { TVTR } \\
\end{array}$} \\
\hline & Coefficient & $\mathbf{Z}$ & $\begin{array}{c}\mathbf{P} \\
\text { value }\end{array}$ & Coefficient & $\mathbf{Z}$ & $\begin{array}{c}\mathbf{P} \\
\text { value }\end{array}$ & Coefficient & $\mathbf{Z}$ & $\begin{array}{c}\mathbf{P} \\
\text { value }\end{array}$ \\
\hline GGDI & 0.96 & 2.45 & 0.014 & 0.938 & 2.19 & 0.028 & 1.087 & 2.22 & 0.026 \\
\hline & & 2.7 & 0.007 & & & 0.050 & & & 0.009 \\
\hline \multirow[t]{2}{*}{ Constant } & 36.301 & 2.44 & 0.015 & 10.391 & 1.18 & 0.237 & -4.412 & -0.43 & 0.668 \\
\hline & \multicolumn{3}{|c|}{$\begin{array}{l}\text { Wald chi-square }(1)= \\
17.54 \\
\text { Prob. of chi-square }= \\
0.0002\end{array}$} & \multicolumn{3}{|c|}{$\begin{array}{l}\text { Wald chi-square (1) }= \\
12.42 \\
\text { Prob. of chi-square }= \\
0.002\end{array}$} & \multicolumn{3}{|c|}{$\begin{array}{l}\text { Wald chi-square }(1)= \\
16.79 \text { = } \\
\text { Prob. of chi-square }= \\
0.0002\end{array}$} \\
\hline
\end{tabular}

Note: Results of random effects models are reported here after estimating both fixed and random effects models and using Hausman test.

\section{Conclusion and Policy Implications}

This paper aims to provide further empirical evidence about the relationship between stock market development and economic growth by utilizing unbalanced panel data from some Arab countries (Bahrain, Egypt, Jordan, Oman, Qatar, Saudi Arabia, Tunis, and United Arab Emirates) over the period (1980 - 2008). The results of the estimated fixed and random effects models indicate that there is a positive effect of stock market development (as measured by Market Capitalization Ratio and Turnover Ratio) on economic growth. This conclusion supports the viewpoints that stock market development can enhance economic growth, and counters the skeptic's point of view that the volatile nature of stock markets and speculation in developing countries may retard economic growth. On the other hand, results of the reverse direction models demonstrate that economic growth has a positive and statistically significant effect on stock market development indicators. Therefore, this study supports the reciprocal relationship between stock market development and economic growth.

The outcomes of this study provide some policy issues in which policy makers in Arab countries should play an active role to foster stock markets in these countries through removing impediments to stock markets, such as legal and regulatory barriers and restrictions on portfolio and dividend flow. Moreover, the international integration of the Arab stock markets should be one of the main concerns of policy makers in these countries. This leaves us with the question; what can Arab governments do to enhance and encourage the creation and active participation of Arab stock markets? 


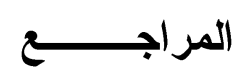

- Agarwal, S. (Spring 2001). "Stock Market Development and Economic Growth: Preliminary Evidence from African Countries", Journal of Sustainable Development in Africa, 3 (1): pp. 48 - 56.

- Azarmi, T.; D. Lazar and J. Jeyapaul. (2005). "Is The Indian Stock Market A Casino?" Journal of Business \& Economics Research, 3 (4): pp. 63-72.

- Baier, S. L.; G. P. Dwyer Jr. and R. Tamura. (2004). "Does Opening a Stock Exchange Increase Economic Growth?” Journal of International Money and Finance, 23 (3): pp. 311-331.

- Bencivenga, V. and B. Smith. (April 1991). "Financial Intermediation and Endogenous Growth.”, The Review of Economic Studies, 58 (2): pp.195-209.

- Bhide, A. (August 1993). "The Hidden Costs of Stock Market Liquidity.", Journal of Financial Economics, 34 (1): pp. 31-51.

- Brasoveanu, L. O.; V. Dragota, D.; Catarama and A. Semenescu. (2008). "Correlations between Capital Market Development and Economic Growth: The Case of Romania", Journal of Applied Quantitative Methods, 3 (1), pp. 64-75.

- Breusch, T. and A. Pagan. (1980). "The LM Test and Its Applications to Model Specification in Econometrics", The Review of Economic Studies, 47 (1): pp. 239-253.

- Capasso, S. (May 2003). "Stock Market Development and Economic Growth: A Matter of Informational Problems", Centre for Growth and Business Cycle Research, School of Economic Studies, University of Manchester, Working Paper No. 32.

- Caporale, G.; P. Howells and A. Soliman. (June 2004). "Stock Market Development and Economic Growth: The Casual Linkage.”, Journal of Economic Development, 29 (1):, PP. 33-50.

- Caporale, G.; P. Howells and A. Soliman. (May 2005). "Endogenous Growth Models and Stock Market Development: Evidence from Four Countries", Review of Development Economics, 9 (2): pp. 166-176.

- Chakraborty, I. (2008). "Does Financial Development Cause Economic Growth? The Case of India”, South Asia Economic Journal, 9 (1): pp. 109-139.

- Choong, C. K.; Z. Yusop; S. H. Law and V. K. Liew. (2005). "Financial Development and Economic Growth in Malaysia: The Perspective of Stock Market", Investment Management and Financial Innovations, 4: pp. 105-115.

- Deb, S. G. and J. Mukherjee. (2008). "Does Stock Market Development Cause Economic Growth? A Time Series Analysis for Indian Economy", International Research Journal of Finance and Economics, 21: pp. 142-149.

- Dritsaki, C. and M. Dritsaki-Bargiota. (2005). "The Causal Relationship between Stock, Credit Market and Economic Development: An Empirical Evidence for Greece", Economic Change and Restructuring, 38 (1): pp. 113 -127.

- Filer, R., J. Hanousek, and N. Campos. (1999). "Do Stock Markets Promote Economic Growth?", William Davidson Institute (WDI), University of Michigan, Working Paper No. 267.

- Goldsmith, R. (1969). Financial Structure and Development. New Haven: Yale University Press.

- Greene, W. H. (2003). Econometric Analysis. $5^{\text {th }}$ Ed. Upper Saddle River, N.J., Prentice Hall. 
- Gurley, J. and E. Shaw (1955), "Financial Aspects of Economic Development.", The American Economic Review, 45 (4): pp. 515-538.

- Gürsoy, C. T. and A. Müslümov. (2000). "Stock Markets and Economic Growth: A Causality Test”, Dogus University Journal, 2: pp: 124 -131.

- Harris, R. (1997). "Stock Markets and Development: A Re-assessment", European Economic Review, 41 (1): pp. 139-46.

- Hausman, J. (1978). “Specification Tests in Econometrics.”, Econometrica, 46(6): pp. 1251-1271.

- Holmstrom, B. and J. Tirole. (August 1993). "Market Liquidity and Performance Monitoring”, Journal of Political Economy, 101 (4): pp. 678-709.

- Howitt, P. (2004). "Endogenous Growth, Productivity and Economic Policy: A Progress Report", International Productivity Monitor, 8: pp. 3-15.

- International Monetary Fund. (October 2009). World Economic Outlook Database.

- Johnston, J. and J. DiNardo .(1997). Econometric Methods.4 ${ }^{\text {th }}$ Ed. New York, McGrawHill.

- King, R. G. and R. Levine .(December 1993). "Finance, Entrepreneurship, and Growth: Theory and Evidence", Journal of Monetary Economics, 32 (3): pp. 513-42.

- Levhari, D. and T. N. Srinivasan .(1969). "Optimal Savings under Uncertainty", The Review of Economic Studies, 36 (2): pp. 153-163.

- Levine, R. (1991). "Stock Markets, Growth and Tax Policy", The Journal of Finance, 46 (4): pp. 1445-1465.

- Levine, R. (June 1993). "Financial Structures and Economic Development.", Revista de Análisis Económico, 8.1: pp. 113-129.

- Levine, R. (June 1997: a). "Financial Development and Economic Growth: Views and Agenda", Journal of Economic Literature, 35 (2): pp. 688-726.

- Levine, R. (December 1997:b). "Stock Markets, Economic Development, and Capital Control Liberalization”, Perspective, Investment Company Institute, Occasional Papers, 3 (5).

- Levine, R. and S. Zervos .(1998). "Stock Markets, Banks, and Economic Growth", The American Economic Review, 88 (3): pp. 537-558.

- Lucas, Robert E. (1988). “On the Mechanics of Economic Development”, Journal of Monetary Economics, 22 (1): pp.3-42.

- McKinnon, R. I. (1973). Money and Capital in Economic Development, Washington, DC., The Brooking Institution.

- Mirman, L. J. (Jan. 1971). "Uncertainty and Optimal Consumption Decisions", Econometrica, 39 (1): pp. 179-185.

- Nieuwerburgh, S. \& F. Buelens, and L. Cuyvers .(2006). "Stock Market Development and Economic Growth in Belgium”, Explorations in Economic History, 43 (1): pp. 13-38.

- Obstfeld, M. (Dec. 1994). "Risk-Taking, Global Diversification, and Growth", The American Economic Review, 84 (5): pp. 1310-1329.

- Osinubi, T. S. (Mar. 2004). "Does Stock Market Promote Economic Growth in Nigeria ?", The ICFAI Journal of Applied Finance, IJAF, 10 (3): pp. 17-35. 
- Oshikoya, T. W. and O. Ogbu. (2002). "Financial Liberalization, Emerging Stock Markets and Economic Developments in Africa", Chapter 13, In: T. Mkandawire and C. Soludo (Eds.), "African Voices on Structural Adjustment: A Companion to Our Continent, Our Future". CODESRIA/Africa World Press, pp. 441-470.

- Patrick, H. T. (1966). "Financial Development and Economic Growth in Underdeveloped Countries", Economic Development and Cultural Change, 14: pp. 174-189.

- Roubini, N and Sala-I-Martin. (1991). The Relation between Trade Regime, Financial Development and Economic Growth. Mimeo: Yale University.

- Rousseau, P. L. and R. Sylla. (2003). "Financial Systems, Economic Growth, and Globalization.”, In: M. D. Bordo, A. M. Taylor and J. G. Williamson (Eds.), Globalization in Historical Perspective. Chicago: University of Chicago Press, , pp. 373-415.

- Shahbaz, M., N. Ahmed, and L. Ali. (2008). "Stock Market Development and Economic Growth: Ardl Causality in Pakistan", International Research Journal of Finance and Economics, 14: pp. 182 - 195.

- Shaw, E. S. (1973). Financial Deepening in Economic Development. New York: Oxford University Press.

- Singh, A. (1997). "Financial Liberalization, Stock Markets and Economic Development", The Economic Journal, 107 (442): pp. 771- 782.

- Solow, R. M. (1956). “A Contribution to the Theory of Economic Growth", Quarterly Journal of Economics, 70: pp. 65-94.

- Standard and Poor Global Stock Markets Fact book. 2005. Washington D. C.

- Stiglitz, J. (1989). "Financial Markets and Development", Oxford Review of Economic Policy, 5: pp. 55-68.

- Toda, H. Y. and T. Yamamoto. (1995). "Statistical Inference in Vector Auto regressions with Possibly Integrated processes”, Journal of Econometrics, 66: pp. 225-250.

- Vazakidis, A. and A. Adamopoulos. (2009). "Financial Development and Economic Growth: An Empirical Analysis for Greece", American Journal of Applied Sciences, 6 (7): pp. 1410-1417.

- Vazakidis, A. and A. Adamopoulos .(2010). "A Causal Relationship between Financial Market Development and Economic Growth", American Journal of Applied Sciences, 7 (4): pp. 575-583.

\section{Appendix (1)}

\section{Sources of Stock Market Data Set}

\begin{tabular}{l|l}
\hline \hline \multicolumn{1}{c|}{ Country } & \multicolumn{1}{c}{ Data source } \\
\hline \hline Bahrain & Bahrain Stock Exchange, Financial Highlights, different issues. \\
Egypt & Egyptian Capital Market Authority (1990-1996) - Cairo \& \\
\hdashline Jordan & Alexandria Stock Exchanges (1997-2008). \\
Oman & Amman Stock Exchange, Annual Report, different issues. \\
Qatar & Muscat Securities Market, Annual Statistical Bulletin 2008. \\
Saudi Arabia & Doha Securities Market, Annual Report 2008. \\
Tunisa & Saudi Arabian Monetary Agency, Forty Fifth Annual Report 2009. \\
Emirates & Tunis Stock Exchange, Annual Report 2008, June 2009. \\
\hline \hline
\end{tabular}

